\title{
Phosphorus use efficiency in pima cotton (Gossypium barbadense L.) genotypes
}

\author{
Elcio Santos $^{1 *}$, Nericlenes Marcante ${ }^{2}$, Takashi Muraoka ${ }^{1}$, and Marcos Camacho $^{3}$
}

In the Brazilian Cerrado, $\mathrm{P}$ deficiency restricts cotton production, which requires large amounts of phosphate fertilizer. To improve the yield of cotton crops, genotypes with high $\mathrm{P}$ use efficiency must be identified and used. The present study evaluated P uptake and use efficiency of different Gossypium barbadense L. genotypes grown in the Cerrado. The experiment was carried out in a greenhouse with a completely randomized design, $15 \times 2$ factorial treatment structure $(15$ genotypes $\times 2$ P levels), and four replicates. The genotypes were MT 69, MT 70, MT 87, MT 91, MT 92, MT 94, MT 101, MT 102, MT 103, MT 105, MT 106, MT 110, MT 112, MT 124, and MT 125; P levels were sufficient (1000 mg pot ${ }^{-1}$, PS treatment) or deficient (PD treatment). Dry matter (DM) and P levels were determined in cotton plant parts and used to calculate plant P content and use efficiency. In general, DM and P content were higher in the PS than in the PD treatment, with the exception of root DM and total DM in some genotypes. Genotypes also differed in terms of P uptake and use capacity. In the PS treatment, genotypes MT 92 and MT 102 had the highest response to phosphate fertilization. Genotype MT 69 exhibited the most efficient P uptake in the PD treatment. Genotype MT 124 showed the best shoot physiological efficiency, apparent recovery efficiency, and utilization efficiency, whereas MT 110 exhibited the highest root physiological efficiency.

Key words: Nutritional efficiency, phosphorus supply, pima cotton.

\section{INTRODUCTION}

Pima cotton (Gossypium barbadense L.) is widely distributed in Brazil and is found in all regions. This species originated in northern Peru and southern Ecuador and is endemic to South America (Zhang et al., 2002). The use of G. barbadense as a source of genetic rusticity in interspecific crossing with $G$. hirsutum $\mathrm{L}$. is capable of providing features, such as tolerance to soils with low P content, which is characteristic of tropical soils. In the second half of the 1990s, cotton crops in Brazil migrated from traditional croplands to the Cerrado because farmers saw an excellent business opportunity for growing cotton in rotation with soybean. Currently, $84 \%$ of cotton production in Brazil is located in the Cerrado. Nevertheless, soil in the Cerrado exhibits certain restrictions, such as high acidity, low fertility, and low $\mathrm{P}$ content and availability (Pavinato et al., 2009).

${ }^{1}$ Universidade de São Paulo, Centro de Energia Nuclear na Agricultura, Av. Centenário, 303, São Dimas, Piracicaba, São Paulo, Brasil. "Corresponding author (elciosantos@cena.usp.br).

${ }^{2}$ Universidade de São Paulo, Escola Superior de Agricultura "Luiz de Queiroz”, Av. Pádua Dias 11, Piracicaba, São Paulo, Brasil.

${ }^{3}$ Universidade Estadual de Mato Grosso do Sul (UEMS), Rodovia Aquidauana/UEMS km 12, CEP 79200-000, Aquidauana, Mato Grosso do Sul, Brasil.

Received: 4 June 2014.

Accepted: 24 February 2015.

doi:10.4067/S0718-58392015000200010
In Brazil, $\mathrm{P}$ is one of the main nutrients used in fertilization (Pavinato et al., 2010) because plants generally exhibit low $\mathrm{P}$ recovery from phosphate fertilizers. Soil P availability is low due to high soil iron and aluminum oxide content (Dorahy et al., 2007), which can be positively charged, thereby adsorbing phosphate anions from particle surfaces (Pavinato et al., 2009). Phosphorus fertilizers are mainly produced from phosphate rocks (Corrêa and Sharma, 2004), which is a limited natural resource. A number of studies have sought sustainable procedures for $\mathrm{P}$ use that preserve natural sources. One solution is to combine the use of plants with good $\mathrm{P}$ use efficiency and good farming practices (Shujie and Yunfa, 2011). However, there are only a few studies that have screened cotton for P efficiency.

The selection of genotypes that tolerate a wide range of nutritional stress conditions has been one of the main contributors to increasing crop yield (Zambrosi et al., 2012). Phosphorus-efficient genotypes within a species are able to grow well and produce high yields in soils with low available P; they are therefore tolerant to P deficiency (Fageria et al., 2010). Considerable intraspecific variations in P efficiency have been identified in a variety of plant species, including cowpea (Araújo et al., 2012), rice (Fageria and Moraes, 2013), and citrus (Zambrosi et al., 2012). The evolution of pima cotton has led to a highly developed root system to penetrate deep soil layers in its natural habitat (Zhang et al., 2002). Thus, we believe that a vigorous root system can give pima cotton enhanced $\mathrm{P}$ 
efficiency and consequently, provide a source of genetic variation to improve cotton P efficiency.

The present study evaluated P uptake and use efficiency of different Gossypium barbadense genotypes grown in the Cerrado.

\section{MATERIALS AND METHODS}

The experiment was carried out in arched greenhouses in the Aquidauana unit of the State University of Mato Grosso do Sul (20²7' S, 5540' W; 174 m a.s.l.), Brazil. According to Köppen-Geiger's classification, climate in the area is Aw (wet tropical) and characterized as tropical wet with a rainy season in the summer and dry in the winter. The 6 $\mathrm{dm}^{3}$ pots were filled with $5 \mathrm{~kg}$ of sandy textured Argissolo Vermelho-Amarelo (Oxisol) soil from the top layer (0$20 \mathrm{~cm}$ ), (Embrapa, 2006), which was sieved in a $2-\mathrm{mm}$ mesh. Before the experiment, soil chemical properties were determined according to methods proposed by van Raij et al. (2001): $5.6 \mathrm{pH}, 15 \mathrm{~g} \mathrm{dm}^{-3}$ organic matter, $4.1 \mathrm{mg}$ $\mathrm{dm}^{-3}$ available $\mathrm{P}$ (resin-extractable), $1.5 \mathrm{mmol}_{\mathrm{c}} \mathrm{K} \mathrm{dm}^{-3}, 30$ $\mathrm{mmol}_{\mathrm{c}} \mathrm{Ca} \mathrm{dm}^{-3}, 14 \mathrm{mmol}_{\mathrm{c}} \mathrm{Mg} \mathrm{dm}{ }^{-3}, 18 \mathrm{mmol}_{\mathrm{c}} \mathrm{H}+\mathrm{Al}$ $\mathrm{dm}^{-3}, 63.5 \mathrm{mmol}_{\mathrm{c}} \mathrm{dm}^{-3}$ cation exchange capacity (CEC), $45.5 \mathrm{mmol}_{\mathrm{c}} \mathrm{dm}^{-3}$ sum of bases, and $72 \%$ base cation saturation. Soil textural analysis was $340 \mathrm{~g}$ clay, $100 \mathrm{~g}$ silt, and $660 \mathrm{~g}$ sand per $\mathrm{kg}$ of soil.

The experiment was completely randomized, arranged in a $15 \times 2$ factorial design with four replicates, and totaled 120 pots. The factors under consideration were $G$. barbadense genotypes (15 levels) and soil P levels, which were sufficient (PS) or deficient (PD). The genotypes, obtained from the Embrapa germplasm bank, were identified as MT 69, MT 70, MT 87, MT 91, MT 92, MT 94, MT 101, MT 102, MT 103, MT 105, MT 106, MT 110, MT 112, MT 124, and MT 125. All the genotypes were collected in the state of Mato Grosso. Three cotton seeds were sown in each pot. Seven days after emergence, plants were thinned to one per pot. An adaptation of Johanson's solution (Epstein and Bloom, 2006) was applied to fertilize the treatments. It contained $4 \mathrm{~mL}$ $\mathrm{KNO}_{3}$ solution $1 \mathrm{~mol} \mathrm{~L}^{-1}, 6 \mathrm{~mL} \mathrm{NH}_{4} \mathrm{NO}_{3}$ solution $1 \mathrm{~mol}$ $\mathrm{L}^{-1}, 2 \mathrm{~mL} \mathrm{MgSO} 47 \mathrm{H}_{2} \mathrm{O}$ solution $1 \mathrm{~mol} \mathrm{~L}^{-1}, 4 \mathrm{~mL} \mathrm{CaCl}_{2}$ solution $1 \mathrm{~mol} \mathrm{~L}^{-1}, 2 \mathrm{~mL} \mathrm{KCL}$ solution $1 \mathrm{~mol} \mathrm{~L}^{-1}, 1.0 \mathrm{~mL}$ $\mathrm{MnSO}_{4} \mathrm{H}_{2} \mathrm{O}$ solution $0.002 \mathrm{~mol} \mathrm{~L}^{-1}, 1 \mathrm{~mL} \mathrm{ZnSO}_{4} 7 \mathrm{H}_{2} \mathrm{O}$ solution $0.002 \mathrm{~mol} \mathrm{~L}^{-1}$, and $1 \mathrm{~mL} \mathrm{CuSO}_{4} 5 \mathrm{H}_{2} \mathrm{O}$ solution $0.0005 \mathrm{~mol} \mathrm{~L}^{-1}$. Phosphorus was applied to plants in the PS treatment at $1000 \mathrm{mg} \mathrm{pot}^{-1}\left(200 \mathrm{mg} \mathrm{P} \mathrm{kg}^{-1}\right.$ soil). The $\mathrm{P}$ source was monobasic ammonium phosphate, which was diluted in deionized water before being administered. The $\mathrm{PD}$ plants did not receive any additional $\mathrm{P}$, but $\mathrm{N}$ addition at $1000 \mathrm{mg} \mathrm{pot}^{-1}\left(200 \mathrm{mg} \mathrm{P} \mathrm{kg}^{-1}\right.$ soil) in plating. The $\mathrm{N}$ source used in the PD plants was urea. Both treatments were watered when necessary.

At $195 \mathrm{~d}$ after emergence (DAE), plants were collected, separated into shoots and roots, washed in deionized water, and oven-dried at $65^{\circ} \mathrm{C}$ for $72 \mathrm{~h}$ to determine root dry matter (RoDM), shoot dry matter (ShDM) and total dry matter (ToDM). The material was then ground in a Wiley-type stainless steel grinding mill. Samples were analyzed to determine P levels by the colorimetric method (Malavolta et al., 1997). Plant DM production and P level data were used to calculate $\mathrm{P}$ content in root (RoP), shoot (ShP), and the entire plant (ToP, total P). The following efficiency parameters were calculated: uptake efficiency $\left(\mathrm{UpE}, \mathrm{mg} \mathrm{g}^{-1}\right)=\mathrm{ToP} / \mathrm{RoDM}$, transport efficiency (TrE, $\mathrm{mg}$ $\left.\mathrm{mg}^{-1}\right)=\mathrm{ShP} / \mathrm{ToP} \times 100$, biological utilization efficiency (BUE, $\left.\mathrm{g}^{2} \mathrm{mg}^{-1}\right)=\mathrm{ToDM}^{2} / \mathrm{ToP}$, shoot physiological efficiency $\left(\mathrm{ShPE}, \mathrm{g} \mathrm{mg}^{-1}\right)=\left(\mathrm{ShDM}_{\mathrm{PS}}-\mathrm{ShDM}_{\mathrm{PD}}\right) /\left(\mathrm{ShP}_{\mathrm{PS}}\right.$ - $\mathrm{ShP} P$ ) root physiological efficiency (RoPE, $\mathrm{g} \mathrm{mg}^{-1}$ ) = $\left(\operatorname{RoDM}_{\mathrm{PS}}-\mathrm{RoDM}_{\mathrm{PD}}\right) /\left(\mathrm{RoP}_{\mathrm{PS}}-\mathrm{RoP}_{\mathrm{PD}}\right)$ apparent recovery efficiency $(\mathrm{ARE}$, percentage $)=\left(\mathrm{ShP} \mathrm{PS}_{\mathrm{S}} \mathrm{ShP} \mathrm{PD}_{\mathrm{PD}}\right) \mathrm{P}_{\text {applied }} \times$ 100, and utilization efficiency $\left(\mathrm{UtE}, \mathrm{g} \mathrm{g}^{-1}\right)=\mathrm{ShPE} \times \mathrm{ARE}$ where ToP is total plant $\mathrm{P}$ content $(\mathrm{mg})$, ShP is shoot $\mathrm{P}$ content $(\mathrm{mg}), \mathrm{ShDM}_{\mathrm{PAdeq}}$ is shoot DM in plants under PS, $\mathrm{ShDM}_{\mathrm{PD}}$ is shoot DM in plants under $\mathrm{PD}, \mathrm{ShP}_{\mathrm{PS}}$ is shoot $\mathrm{P}$ content $(\mathrm{mg})$ in plants under $\mathrm{PS}, \mathrm{ShP}_{\mathrm{PD}}$ is shoot $\mathrm{P}$ content $(\mathrm{mg})$ in plants under PD, RoDM $\mathrm{PS}_{\mathrm{PS}}$ is root $\mathrm{DM}$ in plants under PS, RoDM $\mathrm{PD}_{\mathrm{P}}$ is shoot DM in plants under PD, RoP PS is root $\mathrm{P}$ content $(\mathrm{mg})$ in plants under PS, $\operatorname{RoP}_{\mathrm{PD}}$ is root $\mathrm{P}$ content $(\mathrm{mg})$ in plants under $\mathrm{PD}$, and $\mathrm{P}_{\text {applied }}$ is the amount of applied $\mathrm{P}(\mathrm{mg})$.

Data were analyzed by descriptive statistics and factorial ANOVA as follows:

$$
Y_{i j k}=\mu+\alpha_{i}+\beta_{j}+(\alpha \beta)_{i j}+\varepsilon_{i j k}
$$

where $\mu$ is the overall mean, $\alpha_{i}$ is the effect of the $i^{\text {th }}$ phosphate fertilization level, $\beta_{j}$ is the effect of the $j^{\text {th }}$ genotype, $(\alpha \beta)_{i j}$ is the combined effect of the $i^{\text {th }}$ phosphate fertilization level and $j^{\text {th }}$ genotype, and $\varepsilon_{i j k}$ is the random error effect.

Means were compared according to the F-test (soil P level) and Student's t-test (genotypes) with the SAS package (SAS Institute, Cary, North Carolina, USA).

\section{RESULTS AND DISCUSSION}

\section{Dry matter and phosphorus content}

In general, all genotypes showed significantly reduced growth under limited P supply. However, an exception was observed for the genotypes MT 69, MT 103, MT 105, MT 110, and MT 124 in which RoDM production did not change as a function of $\mathrm{P}$ application (Table 1). The potential for root system development of these genotypes is therefore independent of soil P levels. This characteristic is desirable because a well-developed root system can increase water and nutrient uptake (Katsvairo et al., 2007). According to Fageria and Moraes (2013), nutrient uptake is usually proportional to root development. Only in genotype MT 103 was ToDM production not affected by $\mathrm{P}$ application (Table 1); this is probably because it is less responsive to phosphate fertilization. A decrease in ToDM as a result of $\mathrm{P}$ application is also a useful parameter to evaluate the relative tolerance of cotton varieties to soil 
Table 1. P-value of F-test for dry matter production, phosphorus uptake, and efficiency parameters of Gossypium barbadense genotypes grown under sufficient and deficient phosphate fertilization.

\begin{tabular}{llllcccc}
\hline & RoDM & ToDM & \multicolumn{1}{c}{ RoP } & ToP & UpE & TrE & BUE \\
\hline MT 69 & 0.0603 & 0.0143 & 0.1339 & 0.1523 & 0.9744 & 0.7841 & 0.0067 \\
MT 70 & 0.0013 & 0.0008 & 0.0005 & 0.0004 & 0.3885 & 0.0096 & 0.0044 \\
MT 87 & 0.0005 & 0.0002 & 0.0023 & 0.0003 & 0.7122 & 0.5805 & 0.0014 \\
MT 91 & 0.0098 & 0.0012 & 0.0001 & 0.0480 & 0.3986 & 0.2290 & 0.0075 \\
MT 92 & 0.0003 & 0.0001 & 0.0006 & $<0.0001$ & 0.4766 & 0.8064 & 0.0026 \\
MT 94 & 0.0003 & $<0.0001$ & $<0.0001$ & 0.0024 & 0.2999 & 0.0083 & 0.0020 \\
MT 101 & 0.0207 & 0.0025 & 0.0246 & 0.0014 & 0.1023 & 0.1071 & 0.4802 \\
MT 102 & 0.0104 & 0.0001 & 0.0058 & 0.0003 & 0.0476 & 0.6188 & 0.0028 \\
MT 103 & 0.0637 & 0.0553 & 0.0621 & 0.0754 & 0.5596 & 0.0162 & 0.0029 \\
MT 105 & 0.1167 & 0.0051 & 0.0387 & 0.0298 & 0.0164 & 0.5467 & 0.1299 \\
MT 106 & 0.0028 & 0.0029 & 0.0047 & 0.0019 & 0.5005 & 0.2246 & 0.0201 \\
MT 110 & 0.1017 & 0.0200 & 0.7312 & 0.0052 & 0.0364 & 0.0323 & 0.3698 \\
MT 112 & 0.0012 & $<0.0001$ & 0.0014 & 0.0010 & 0.0609 & 0.3230 & 0.0050 \\
MT 124 & 0.064 & 0.0180 & 0.1157 & 0.0424 & 0.6896 & 0.5560 & 0.0215 \\
MT 125 & 0.0252 & 0.0142 & 0.0750 & 0.0151 & 0.5500 & 0.3040 & 0.0163 \\
\hline
\end{tabular}

RoDM: Root dry matter, ToDM: total dry matter, RoP: root P content, ToP total $\mathrm{P}$ content, UpE: uptake efficiency, TrE: transport efficiency, BUE: biological utilization efficiency.

Statistical significance was set at 0.05 error probability.

P deficiency (Dorahy et al., 2004). Cotton genotypes that do not change DM production in response to $\mathrm{P}$ supply (sufficient or deficient) are best grown in soils with low $\mathrm{P}$ content (Wang et al., 2008).

Genotypes produced different RoDM and ToDM in the PS and PD treatments (Table 2). In the PS treatment, RoDM varied significantly from other genotypes, ranging from 4.89 (MT 110) to $13.28 \mathrm{~g} \mathrm{pot}^{-1}$ (MT 92). In the PD treatment, the highest RoDM was obtained in MT 105 with $6.43 \mathrm{~g} \mathrm{pot}^{-1}$. Genotypes capable of producing high RoDM under nutritional stress are likely to achieve high agronomic yield given that the development of an extensive root system allows the exploitation of a larger soil volume (Fageria and Moraes, 2013). In the PS treatment, the range of variation in ToDM production was higher $(24.32 \mathrm{~g}$ pot $\left.^{-1}\right)$ than in the PD treatment $\left(8.15 \mathrm{~g} \mathrm{pot}^{-1}\right)($ Table $2)$. The large variation in the PS treatment indicates that $G$. barbadense genotypes are more responsive

Table 2. Mean values for root dry matter (RoDM) and total dry mater (ToDM) of Gossypium barbadense genotypes grown under sufficient (PS) and deficient (PD) phosphate fertilization.

\begin{tabular}{lrrrrr}
\hline & \multicolumn{2}{c}{ PS } & \multicolumn{2}{c}{ PD } \\
\cline { 2 - 3 } \cline { 5 - 6 } Genotype & RoDM & ToDM & & RoDM & ToDM \\
\cline { 2 - 3 } MT69 & 6.04 & 20.34 & & 2.11 & 6.35 \\
MT70 & 8.67 & 24.11 & & 1.84 & 5.09 \\
MT87 & 11.48 & 27.17 & & 2.88 & 5.83 \\
MT91 & 9.27 & 25.36 & & 3.53 & 8.23 \\
MT92 & 13.28 & 38.66 & & 0.64 & 3.61 \\
MT94 & 9.36 & 24.61 & & 2.77 & 9.55 \\
MT101 & 8.65 & 27.01 & 2.75 & 7.22 \\
MT102 & 8.58 & 28.25 & & 3.23 & 9.65 \\
MT103 & 5.74 & 14.34 & & 2.25 & 6.45 \\
MT105 & 11.54 & 24.43 & 6.43 & 11.76 \\
MT106 & 11.43 & 20.88 & 2.73 & 6.40 \\
MT110 & 4.89 & 14.63 & 3.03 & 7.91 \\
MT112 & 10.95 & 26.60 & 3.56 & 8.51 \\
MT124 & 12.34 & 32.16 & 4.14 & 9.41 \\
MT125 & 7.90 & 18.46 & 2.96 & 7.02 \\
MSD & 0.29 & 0.53 & 0.14 & 0.27 \\
CV, \% & 20.79 & 24.71 & 20.92 & 20.37 \\
\hline
\end{tabular}

$\mathrm{CV}$ : Coefficient of variance, MSD: minimum significant difference. to $\mathrm{P}$ application. Responsive genotypes are more productive and can thus be used as a criterion for selecting and evaluating varieties according to their nutritional efficiency (Fageria et al., 2010).

Root $\mathrm{P}(\mathrm{RoP})$ and entire plant (ToP, total $\mathrm{P})$ content was affected by $\mathrm{P}$ application in most evaluated genotypes. Genotypes that did not change RoP in the PS treatment were MT 69, MT 103, MT 110, and MT 124, and those that did not change ToP were MT 69 and MT 103 (Table 1). The nature of the RoP and ToP variation was specific to the different genotypes (Table 3). In the PS treatment, accumulated RoP ranged from 21.93 to $6.36 \mathrm{mg}$ among genotypes, and ToP was higher in genotypes MT 92 (96.29 $\mathrm{mg}$ ), MT 101 (81.66 mg), and MT 124 (70.60 mg). In the PD treatment, some genotypes showed significant ToP loss with $91 \%$ reduction for MT 92 and $87 \%$ for MT 101 (Table 3). This significant decrease indicates the inability of these genotypes to accumulate P under P-deficiency stress conditions (Fageria et al., 2010).

\section{P uptake, transport, and biological utilization efficiency}

The current study allowed the determination of the genotypic variation in $\mathrm{P}$ efficiency and the observation of the nutritional features of pima cotton under sufficient and deficient $\mathrm{P}$ supply conditions. No similar study about pima cotton has yet to be reported. Uptake efficiency, TrE, and BUE varied according to $\mathrm{P}$ application (Table 1) and genotypes (Table 4). Genotypes MT 102, MT 105, and MT 110 improved UpE when cropped in the PS treatment (Table 1). Only the remaining genotypes exhibited efficient $\mathrm{P}$ uptake because their results were similar in both the PD and PS treatments. In the PS treatment, genotypes MT 69, MT 91, MT 92, MT 101, MT 102, and MT 110 showed the most efficient $\mathrm{P}$ uptake. The $\mathrm{P}$ supply resulted in increased $\mathrm{UpE}$ for these genotypes (Table 1), suggesting higher nutrient concentrations in the soil that promote better

Table 3. Mean phosphorus content in roots $(\mathrm{RoP})$ and entire plant (ToP) of Gossypium barbadense genotypes grown under sufficient (PS) and deficient (PD) phosphate fertilization.

\begin{tabular}{|c|c|c|c|c|}
\hline \multirow[b]{2}{*}{ Genotype } & \multicolumn{2}{|c|}{ PS } & \multicolumn{2}{|c|}{ PD } \\
\hline & RoP & ToP & RoP & ToP \\
\hline MT69 & 10.85 & 49.91 & 5.61 & 22.43 \\
\hline MT70 & 14.10 & 47.49 & 1.61 & 11.71 \\
\hline MT87 & 16.85 & 45.88 & 4.69 & 13.63 \\
\hline MT91 & 15.16 & 60.53 & 2.46 & 22.07 \\
\hline MT92 & 21.93 & 96.29 & 0.71 & 8.98 \\
\hline MT94 & 17.70 & 49.39 & 2.84 & 22.45 \\
\hline MT101 & 11.58 & 81.66 & 3.31 & 10.93 \\
\hline MT102 & 12.42 & 58.74 & 2.65 & 12.08 \\
\hline MT103 & 10.02 & 32.81 & 1.92 & 12.07 \\
\hline MT105 & 19.41 & 46.26 & 6.99 & 14.45 \\
\hline MT106 & 21.60 & 43.14 & 3.71 & 9.23 \\
\hline MT110 & 6.36 & 36.49 & 7.43 & 14.00 \\
\hline MT112 & 16.53 & 56.75 & 3.87 & 10.73 \\
\hline MT124 & 15.84 & 70.60 & 6.94 & 15.84 \\
\hline MT125 & 15.31 & 41.08 & 7.41 & 16.28 \\
\hline MSD & 0.49 & 1.53 & 0.23 & 0.65 \\
\hline $\mathrm{CV}, \%$ & 15.80 & 15.26 & 20.12 & 25.81 \\
\hline
\end{tabular}

CV: Coefficient of variance, MSD: minimum significant difference. 
efficiency in roots in the absorption process, as already observed for other crops (Zambrosi et al., 2012). Uptake efficiency mostly increased because of the positive effect of P supply in RoP and ToP (Table 3) under sufficient phosphate fertilization. In the PD treatment, only MT 69, MT 91, MT 92, and MT 94 had a greater capacity to extract soil nutrients (Table 4). Different UpE in genotypes observed in the present study can result from diversified plant morphology, particularly the ability to develop secondary roots (Baligar et al., 2001; Lynch and Ho, 2005). These peculiarities can be used to indicate genotypes that can cope with P-deficiency stress and P uptake.

Comparing treatments for each genotype (MT 70, MT 94, MT 103, and MT 110) showed no changes in TrE in response to $\mathrm{P}$ application (Table 1). Genotypes MT 70, MT 94, and MT 103 increased TrE (Tables 1 and 4) in the PD treatment, indicating that nutrient transport from root to shoot is more efficient under P-deficiency stress conditions (Baligar et al., 2001). On the other hand, genotype MT 110 drastically reduced TrE when it was cropped in the PD treatment, suggesting that $\mathrm{P}$ transport in this variety is promoted by an increase in soil P. Genotypes MT 69, MT 70, MT 91, MT 92, MT 101, and MT 102 exhibited high TrE in both the PS and PD treatments (Table 4), reflecting high productive potential. These genotypes are responsive to $\mathrm{P}$ application and efficient in transporting this nutrient. A study with beans showed a significant relationship between crop production and $\mathrm{P}$ transport from root to shoot (Fageria et al., 2010).

Only genotypes MT 101, MT 105, and MT 110 exhibited the same BUE between the PS and PD treatments, that is, the same capacity for converting absorbed nutrients into DM (Table 1). In the PS treatment, BUE ranged from 16.27 (MT 124) to 5.99 (MT 110) $\mathrm{g} \mathrm{g}^{-1}$, while in the PD treatment, it ranged from 9.67 to 1.59

Table 4. Phosphorus uptake and use efficiency (mean values) of Gossypium barbadense genotypes grown under sufficient (PS) and deficient (PD) phosphate fertilization.

\begin{tabular}{|c|c|c|c|c|c|c|}
\hline \multirow[b]{2}{*}{ Genotype } & \multicolumn{3}{|c|}{ PS } & \multicolumn{3}{|c|}{ PD } \\
\hline & UpE & $\operatorname{TrE}$ & BUE & $\mathrm{UpE}$ & $\operatorname{TrE}$ & BUE \\
\hline & & & & & & \\
\hline MT69 & 9.21 & 75.93 & 8.52 & 9.34 & 77.78 & 2.18 \\
\hline MT70 & 5.58 & 69.96 & 12.40 & 6.85 & 86.26 & 2.26 \\
\hline MT87 & 4.00 & 63.26 & 16.10 & 4.29 & 53.50 & 3.64 \\
\hline MT91 & 6.90 & 71.91 & 11.53 & 10.12 & 84.16 & 1.59 \\
\hline MT92 & 7.49 & 77.17 & 15.78 & 20.28 & 80.07 & 1.78 \\
\hline MT94 & 5.74 & 64.79 & 11.46 & 9.58 & 87.19 & 4.32 \\
\hline MT101 & 10.42 & 85.31 & 9.30 & 4.26 & 68.10 & 6.70 \\
\hline MT102 & 7.32 & 79.04 & 13.71 & 3.95 & 72.76 & 7.92 \\
\hline MT103 & 4.39 & 59.82 & 10.79 & 7.54 & 83.69 & 3.54 \\
\hline MT105 & 4.47 & 64.46 & 13.37 & 2.50 & 56.39 & 9.67 \\
\hline MT106 & 3.82 & 50.92 & 10.18 & 3.39 & 62.59 & 4.72 \\
\hline MT110 & 7.86 & 82.69 & 5.99 & 4.59 & 49.56 & 4.67 \\
\hline MT112 & 5.27 & 70.26 & 12.57 & 3.00 & 63.85 & 7.73 \\
\hline MT124 & 4.24 & 61.73 & 16.27 & 3.73 & 52.86 & 5.86 \\
\hline MT125 & 5.34 & 64.07 & 8.33 & 5.83 & 52.34 & 3.09 \\
\hline MSD & 0.23 & 0.87 & 0.28 & 0.73 & 1.36 & 0.16 \\
\hline $\mathrm{CV}, \%$ & 20.62 & 14.01 & 18.12 & 24.28 & 22.13 & 12.42 \\
\hline
\end{tabular}

UpE: uptake efficiency, TrE: transport efficiency, BUE: biological utilization efficiency, CV: coefficient of variance, MSD: minimum significant difference. $\mathrm{g} \mathrm{g}^{-1}$. In another study, significant BUE differences were observed in six cotton genotypes cropped under both low and sufficient $\mathrm{P}$ conditions (Wang et al., 2008). In the present study, it was higher in MT 102, MT 105, and MT 112 for the PS and PD treatments (Table 4). High BUE genotypes are recommended for cropping in soil with low $\mathrm{P}$ availability because they can better redistribute minerals from senescent organs by reutilizing these nutrients in metabolic processes such as plant growth (Fageria et al., 2010). Under P-deficiency conditions, BUE is increased as a result of changes in activity of glycolysis enzymes on the route, which will start operating in alternative pathways of carbohydrate catabolism during disability, contribute to more $\mathrm{P}$ use by efficient recycling reduction consumption, and use other fractions of the nutrient (Mengel and Kirkby, 2001; Marschner, 2012).

Plant properties and characteristics related to $\mathrm{P}$ uptake and utilization are heritable and will, no doubt, be exploited more vigorously as fertilizer costs continue to increase for cotton cultivation. Inter- and intraspecific variations for plant growth and mineral nutrient use efficiency are known to be under genetic and physiological control and modified by plant interactions with environmental variables (Baligar et al., 2001). Baligar et al. (2001) also reported that identifying traits, such as nutrient absorption, transport, utilization, and mobilization, in plant cultivars should greatly enhance fertilizer use efficiency.

Physiological efficiency, apparent recovery, and utilization efficiency of $P$

Data on ShPE, ARE, UtE, and RoPE are shown in Table 5. These efficiency parameters indicate the relative production of the genotypes in soils that are deficient compared with production in soils containing optimal nutrient levels. The highest ShPE values were found in

Table 5. Physiological phosphorus use efficiency (mean values) of Gossypium barbadense grown under sufficient and deficient phosphate fertilization.

\begin{tabular}{|c|c|c|c|c|}
\hline Genotype & ShPE & RoPE & ARE & UtE \\
\hline & & $\mathrm{g} \mathrm{g}^{-1}$ & $\%$ & $\mathrm{~g} \mathrm{~g}^{-1}$ \\
\hline MT69 & 0.35 & 0.89 & 3.43 & 1.20 \\
\hline MT70 & 0.54 & 0.55 & 2.33 & 1.26 \\
\hline MT87 & 0.56 & 0.72 & 2.27 & 1.27 \\
\hline MT91 & 0.89 & 0.43 & 2.48 & 2.21 \\
\hline MT92 & 0.34 & 0.60 & 6.61 & 2.25 \\
\hline MT94 & 1.14 & 0.44 & 1.13 & 1.29 \\
\hline MT101 & 0.23 & 0.74 & 6.44 & 1.48 \\
\hline MT102 & 0.37 & 0.52 & 3.69 & 1.36 \\
\hline MT103 & 1.55 & 0.44 & 0.89 & 1.38 \\
\hline MT105 & 0.47 & 0.38 & 1.81 & 0.85 \\
\hline MT106 & 0.35 & 0.49 & 1.60 & 0.56 \\
\hline MT110 & 0.21 & 1.47 & 2.36 & 0.49 \\
\hline MT112 & 0.33 & 0.54 & 3.36 & 1.11 \\
\hline MT124 & 0.81 & 0.75 & 6.06 & 4.91 \\
\hline MT125 & 0.38 & 0.56 & 1.69 & 0.64 \\
\hline MSD & 0.0415 & 0.0119 & 0.9939 & 0.2496 \\
\hline $\mathrm{CV}, \%$ & 8.93 & 22.56 & 26.75 & 20.38 \\
\hline
\end{tabular}

ShPE: shoot physiological efficiency, RoPE: root physiological efficiency, ARE: apparent recovery efficiency, UtE: utilization efficiency, CV: coefficient of variance, MSD: minimum significant difference. 
MT 91, MT 94, MT 103, and MT 124 with ShDM of $0.89,1.14,1.55$, and $0.81 \mathrm{~g}$ (per $\mathrm{g}$ applied $\mathrm{P}$ ), respectively (Table 5). Genotype MT 110 showed the highest root production ( $\mathrm{RoPE}=1.47 \mathrm{~g} \mathrm{~g}^{-1}$ ) and the lowest shoot production. Physiological efficiency indicates higher DM production capacity with sufficient nutritional supply compared with a nutritional stress situation (Fageria et al., 2009). Thus, MT 110 was more efficient in producing roots than shoots. Genotypes with this characteristic can be suggested for cropping under low P supply conditions where plants must be more efficient in producing roots that achieve higher soil exploitation. When P limits plant growth, roots become a strong carbohydrate sink, limiting shoot rather than root growth (Wang et al., 2010). Bean roots grown under P-deficiency conditions show higher sugar levels than those grown under sufficient $\mathrm{P}$ supply because of higher photoassimilate transport from shoot to root (Wang et al., 2008).

With regards to ARE, it was higher in MT 101, MT 92, and MT 124 than in other genotypes, and it exhibited, on the average, $6 \%$ of accumulated $\mathrm{P}$ in the plant per applied $\mathrm{P}$ unit. This result shows the best $\mathrm{P}$ recovery from fertilizer by these genotypes (Wang et al., 2008). Cotton response to soil $\mathrm{P}$ application in soil in the Cerrado is higher than that of rice cropped under similar conditions in the highlands. Santos and Fageria (2007) found that crop yield is positively related to nutrient recovery. For UtE, MT 92 and MT 124 were the most efficient genotypes with 22.41 and $20.24 \mathrm{~g} \mathrm{~g}^{-1}$, respectively. Utilization efficiency is the result of a positive interaction between uptake, transport, and nutrient redistribution. The high $\mathrm{UtE}$ of these genotypes was mainly expressed by the corresponding ARE means, which were also high. Utilization efficiency is usually associated with productivity, that is, the higher the UtE, the higher the grain production (Shujie and Yunfa, 2011).

\section{CONCLUSIONS}

Significant differences in shoot dry weight, shoot $\mathrm{P}$ concentration, $\mathrm{P}$ uptake, and $\mathrm{P}$ use index were found among the 15 pima cotton genotypes under sufficient and deficient $\mathrm{P}$ supply. Pima cotton genotypes differed regarding uptake capacity and P use: MT 92 and MT 102 were the most responsive to $\mathrm{P}$ application, MT 69 was the most efficient in $\mathrm{P}$ uptake in crops grown under low P levels, MT 124 produced the highest shoot physiological efficiency, apparent recovery efficiency, and utilization efficiency, and MT 110 showed the highest root physiological efficiency.

\section{ACKNOWLEDGEMENTS}

We thank the Fundação de Apoio ao Desenvolvimento do Ensino, Ciência e Tecnologia do Estado de Mato Grosso do Sul (Fundect) for financial support, and to EMBRAPA for providing the genotypes tested in the study.

\section{LITERATURE CITED}

Araújo, E.O., E.F. Santos, G.Q. Oliveira, M.A., Camacho, and D.M. Dresch. 2012. Nutritional efficiency of cowpea varieties in the absorption of phosphorus. Agronomia Colombiana 30:419-424.

Baligar, V.C., N.K. Fageria, and Z.L. He. 2001. Nutrient use efficiency in plants. Communications in Soil Science and Plant Analysis 32:921-950.

Corrêa, J.C., e R.D. Sharma. 2004. Produtividade do algodoeiro herbáceo em plantio direto no cerrado com rotação de culturas. Pesquisa Agropecuária Brasileira 39:41-46.

Dorahy, C.G., G.J. Blair, I.J. Rochester, and A.R. Till. 2007. Availability of $\mathrm{P}$ from 32P-labelled endogenous soil $\mathrm{P}$ and 33P-labelled fertilizer in an alkaline soil producing cotton in Australia. Soil Use and Management 23:192-199.

Dorahy, C.D., I.J. Rochester, and G.J. Blair. 2004. Response of field grown cotton (Gossypium hirsutum L.) to phosphorus fertilization on alkaline soils in eastern Australia. Australian Journal of Soil Research 42:913-920.

Embrapa. 2006. Centro Nacional de Pesquisa de Solos. Sistema brasileiro de classificação de solos. 2a ed. 306 p. Empresa Brasileira de Pesquisa Agropecuária (Embrapa), Rio de Janeiro, Brasil.

Epstein, E., e A.J. Bloom. 2006. Nutrição mineral de plantas: Princípios e perspectivas. 2a ed. 399 p. Editora Planta, Londrina, Paraná, Brasil.

Fageria, N.K., V.C. Baligar, A. Moreira, and T.A. Portes. 2010. Dry bean genotypes evaluation for growth, yield components and phosphorus use efficiency. Journal of Plant Nutrition $33: 2167-2181$

Fageria, N.K., and M.F. Moraes. 2013. Phosphorus nutrition of lowland rice in tropical lowland soil. Communications in Soil Science and Plant Analysis 44:2932-2940.

Fageria, N.K., A.B. Santos, and V.A. Cutrim. 2009. Nitrogen uptake and its association with grain yield in lowland rice genotypes. Journal of Plant Nutrition 32:1965-1974.

Katsvairo, T.W., D.L. Wright, J.I. Marois, D.L. Hartzog, K.B. Balkcom, P.P. Wiatrak, et al. 2007. Cotton roots, earthworms, and infiltration characteristics in sod-peanut-cotton cropping systems. Agronomy Journal 99:390-398.

Lynch J.P., and M.D. Ho. 2005. Rhizoeconomics: carbon costs of phosphorus acquisition. Plant and Soil 69:45-56.

Malavolta, E., G.C. Vitti, e S.A. Oliveira. 1997. Avaliação do estado nutricional das plantas: princípios e aplicações. $2^{\mathrm{a}}$ ed. 319 p. Potafos, Piracicaba, São Paulo, Brasil.

Marschner, P. 2012. Marschner's mineral nutrition of higher plants. $3^{\text {rd }}$ ed. 651 p. Academic Press, London, UK.

Mengel, K., and E. Kirkby. 2001. Principles of plant nutrition. $5^{\text {th }}$ ed. 849 p. Kluwer Academic Publishers, Dordrecht, The Netherlands.

Pavinato, P.S., T. Dao, and C.A. Rosolem. 2010. Tillage and phosphorus management effects on enzyme-labile bioactive phosphorus availability in Cerrado Oxisols. Geoderma 156:207-215.

Pavinato, P.S., A. Merlin, and C.A. Rosolem. 2009. Phosphorus fractions in Brazilian Cerrado soils as affected by tillage. Soil \& Tillage Research 105:149-155. 
Santos, A.B., e N.K. Fageria. 2007. Manejo do nitrogênio para eficiência de uso por cultivares de feijoeiro em várzea tropical. Pesquisa Agropecuária Brasileira 42:1237-1248.

Shujie, M., and Q. Yunfa. 2011. Effects of phosphorus concentration on adaptive mechanisms of high- and low-P efficiency soybean genotypes when grown in solution. Plant, Soil and Environment 57:61-66.

van Raij, B., J.C. Andrade, H. Cantarella, e J.A. Quaggio. 2001. Análise química para avaliação da fertilidade de solos tropicais. 285 p. Instituto Agronômico, Campinas, São Paulo, Brasil.

Wang, X.R., J. Shen, and H. Liao. 2010. Acquisition or utilization, which is more critical for enhancing phosphorus efficiency in modern crops. Plant Science 179:302-306.
Wang, X., C. Tang, C.N. Guppy, and P.W.G. Sale. 2008. Phosphorus acquisition characteristics of cotton (Gossypium hirsutum L.), wheat (Triticum aestivum L.) and white lupin (Lupinus albus L.) under P deficient conditions. Plant and Soil 312:117-128.

Zambrosi, F.C., D. Mattos Junior, R. Furlani, J.A. Quaggio, and R.M. Boaretto. 2012. Efficiency of phosphorus uptake and utilization in citrus rootstocks. Revista Brasileira de Ciência do Solo 36:486-496.

Zhang, J., W. Guo, and T. Zhang. 2002. Molecular linkage map of allotetraploid cotton (Gossypium hirsutum L. $\times$ Gossypium barbadense L.) with a haploid population. Theoretical and Applied Genetics 105:1166-1174. 